\title{
Pengaruh Penguasaan Kosakata dan Minat Baca terhadap Keterampilan Menulis Teks Deskriptif Bahasa Indonesia
}

\author{
Siti Sundari ${ }^{1)}$ \\ Universitas Indraprasta PGRI \\ Jalan Nangka No. 58 C/TB. Simatupang, Tanjung Barat, Jakarta Selatan 12530 \\ Sumaryoto ${ }^{2)}$ \\ Universitas Indraprasta PGRI \\ Jalan Nangka No. 58 C/TB. Simatupang, Tanjung Barat, Jakarta Selatan 12530 \\ Mamik Suendarti ${ }^{3}$ ) \\ Universitas Indraprasta PGRI \\ Jalan Nangka No. 58 C/TB. Simatupang, Tanjung Barat, Jakarta Selatan 12530 \\ sundari.smk6@gmail.com ${ }^{1)}$
}

\begin{abstract}
The objectives of this study were to determine the effect of vocabulary mastery and reading interest together on the skills of writing descriptive texts in Indonesian of students of State Vocational High Schools in South Jakarta, to determine vocabulary mastery of writing skills of Indonesian descriptive texts, to determine the effect of reading interest on writing skills of Indonesian descriptive texts. The sample used was 60 students as the research sample using proportional random sampling technique from all public vocational high school students in South Jakarta. Data collection was carried out by providing conceptual understanding texts and distributing questionnaires. Data analysis consisted of testing research instruments with validity and reliability tests. Furthermore, the analysis requirements test was carried out with the normality test and homogeneity test. Hypothesis testing with the 2-way Anova test. Based on the results of the hypothesis and data analysis, the following conclusions are as follows there is a significant influence on vocabulary mastery and reading interest together on the writing skills of Indonesian students' narrative text in SMK Negeri in South Jakarta. This is evidenced by the value of Sig $=0.000<0.05$ and Fcount $=74.051$, which means that the regression is significant, There is a significant effect of vocabulary mastery on writing skills of descriptive text Indonesian students of SMK Negeri in South Jakarta This is evidenced by the value of Sig $=0.000<0.05$ and tcount 7, 134 which means that there is a significant effect.
\end{abstract}

Keywords: influence of vocabulary, reading interest, writing skills, descriptive text

\begin{abstract}
Abstrak
Tujuan dari penelitian ini adalah untuk mengetahui pengaruh penguasaan kosakata dan minat baca secara bersama-sama terhadap keterampilan menulis teks deskriptif bahasa Indonesia siswa SMK Negeri di Jakarta Selatan, untuk mengetahui penguasaan kosakata terhadap keterampilan menulis teks deskriptif bahasa Indonesia, dan untuk mengetahui pengaruh minat baca terhadap keterampilan menulis teks deskriptif bahasa Indonesia. Sampel yang digunakan 60 siswa sebagai sampel penelitian menggunakan Teknik proporsional random sampling dari seluruh siswa SMK negeri di Jakarta Selatan. Pengumpulan data dilaksanakan dengan pemberian teks pemahaman konsep dan penyebaran angket. Analisa data terdiri dari pengujian instrument penelitian dengan uji validitas, reabilitas. Selanjutnya dilakukan uji persyaratan analisis dengan uji normalitas dan uji homogenitas. Pengujian hipotesis dengan uji Anova 2 jalur. Berdasarkan hasil hipotesis dan
\end{abstract}

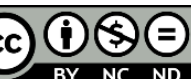

Creative Commons Attribution-NonCommercial-NoDerivatives 4.0 International License 
analisis data adanya pengaruh yang signifikan penguasaan kosakata dan minat baca secara bersama-sama terhadap keterampilan menulis teks naratif bahasa Indonesia siswa SMK Negeri di Jakarta Selatan. Hal ini dibuktikan dengan nilai Sig $=0,000<0,05$ dan Fhitung = 74,051 yang berarti regresi tersebut signifikan, terdapat pengaruh yang signifikan penguasaan kosakata terhadap keterampilan menulis teks deskriptif bahasa Indonesia siswa SMK Negeri di Jakarta Selatan. Hal ini dibuktikan dengan nilai Sig $=0,000<0,05$ dan thitung 7, 134 yang berarti terdapat pengaruh signifikan.

Kata kunci: pengaruh kosakata, minat baca, keterampilan menulis, teks deskriptif

\section{PENDAHULUAN}

Bahasa dipandang sebagai alat yang efektif untuk menciptakan peserta didik yang tangguh dan kompetitif (Tarigan, 2005: 12). Oleh karena itu, dalam pembelajaran bahasa Indonesia dikembangkan empat aspek keterampilan berbahasa di antaranya: (1) membaca, (2) menyimak, (3) berbicara dan (4) menulis.

Bahasa tidak lepas dari yang namanya kosakata. Menurut Poerwadarminta (2007:524) disebutkan bahwa kosakata diartikan sebagai perbendaharaan kata. Dalam bahasa Inggris diistilahkan Vocabulary. Pada Kamus Inggris-Indonesia, kosakata berarti perbendaharaan kata atau daftar kata. Pengertian yang lebih luas kosakata diartikan : Semua kata yang terdapat dalam satu bahasa; Kosakata yang dipakai segolongan orang; Kosakata yang digunakan dalam satu bidang ilmu; Seluruh morfem yang ada dalam satu bahasa (linguistik); Daftar sejumlah kata dari suatu bahasa yang disusun secara urut berdasarkan huruf abjad disertai keterangan.

Belajar menulis karangan deskripsi amat penting karena dengan menguasai menulis deskripsi, peserta didik akan mampu mengekspresikan pikiran dan perasaannya secara cerdas sesuai konteks dan situasi tertentu. Hasil belajar menulis deskripsi juga akan mampu mmbentuk generasi masa depan yang kreatif sehingga mampu melahirkan tuturan atau ujaran yang komunikatif, jelas, runtut, dan mudah dipahami. Selain itu, hasil belajar menulis deksripsi juga akan mampu melahirkan generasi masa depan yang kritis karena mereka memiliki kemampuan untuk mengekspresikan gagasan, pikiran, atau perasaan kepada orang lain secara runtut dan sistematis.

Kemampuan hasil belajar menulis deskripsi merupakan bagian dari aspek yang dikembangkan dalam pembelajaran bahasa Indonesia sesuai dengan tujuan pengajaran mata pelajaran bahasa Indonesia di Sekolah Menengah Pertama yaitu membina keterampilan berbahasa secara lisan dan tertulis serta dapat menggunakan Bahasa sebagai alat komunikasi.

Kemampuan menulis deskripsi sangat didukung oleh pengetahuan penulis yang antara lain dengan banyak membaca. Pada kenyataannya minat membaca di Sekolah Menengah Pertama di Jakarta semakin menurun. Hal tersebut dapat diketahui, misalnya pada saat siswa diberi tugas seperti pekerjaan rumah mereka sering mengerjakannya di sekolah atau langsung mencontek dari pekerjaan teman mereka sebelum belajar dimulai. Budaya membaca perlu ditingkatkan karena membaca merupakan jendela ilmu pengetahuan. Dengan demikian, membaca itu sangat diperlukan dalam kehidupan manusia. 
Menulis adalah salah satu dari keterampilan bahasa. Untuk menulis diperlukan proses berpikir kreatif. Banyak siswa yang mengalami kesulitan saat mereka diberikan tugas oleh guru bahasa Indonesia dalam menulis karangan deskripsi. Teks atau karangan deskriptif adalah suatu bentuk sistem komunikasi lambang visual. Agar komunikasi lewat lambang tulis dapat seperti yang diharapkan, penulis hendaklah menuangkan gagasannya ke dalam bahasa yang tepat, teratur, dan lengkap. Bahasa yang teratur merupakan manifestasi pikiran yang teratur pula (Nurgiyantoro, 2001: 296). Hal ini dapat terjadi karena siswa kurang mampu mengembangkan berpikir kreatif, tidak memiliki kemampuan merangkai kalimat, tidak memiliki penguasaan kosakata yang banyak sehingga kurang dapat mengeksplorasi bahasa dan sebagainya. Penguasaan kalimat dapat dilatih apabila siswa mampu menguasai kosa kata dan memahami cara menulis karangan deskripsi. Bagi siswa kemampuan menulis yang baik dapat menjadi tolak ukur keberhasilan belajar, karena dirinya dapat menjadi manusia yang terampil, kreatif, dan produktif menghasilkan sebuah karangan deskripsi.

Sokmen (Decarrico, 2002: 286) mengemukakan beberapa prinsip pembelajaran kosakata secara eksplisit. Prinsip-prinsip tersebut antara lain memperkaya kosakata, menyatukan kosakata baru dengan dengan kosakata yang sudah dikuasai, menyediakan kosakata baru, meningkatkan pemahaman, membantu memahami makna, menggunakan beragam teknik, dan mendorong penggunaan strategi belajar mandiri. Brown (2001: 377-378) memberikan rambu-rambu pengajaran kosakata yang komunikatif yaitu : ada waktu khusus untuk pembelajaran kosakata, siswa belajar kosakata dalam konteks, penggunaan kamus monolingual ditingkatkan, dan Siswa didorong untuk mengembangkan strategi untuk menebak makna kata.

Membaca menurut Kridalaksana dalam Rachmawati (2005: 3) bahwa membaca adalah keterampilan mengenal dan memahami tulisan dalam bentuk urutan lambang-lambang grafis dan perubahannya menjadi wicara bermakna dalam bentuk pemahaman diam atau pengujaran keras. Akhadiah (2002:22) mengungkapkan bahwa membaca merupakan suatu kesatuan kegiatan seperti mengenali huruf dan kata-kata menghubungkannya dengan bunyi serta maknanya, serta menarik kesimpulan mengenai maksud jawaban.

Rohman (2005: 1-2) mengemukakan bahwa membaca merupakan proses psikologis. Proses psikologi tentang peristiwa membaca yaitu dengan cahaya, bacaan masuk ke mata dan oleh saraf sensorik sebagai reseptor diteruskan ke pusat bahasa yaitu pembentukan kalimat dan langsung ke pusat organisasi berpikir. Setelah diolah melalui proses transtendensi dikembalikan melalui reseptor di mulut dan alat-alat ucap maka terjadilah peristiwa membaca.

Tujuan membaca menurut Nurhadi (2000:12) bahwa tujuan membaca akan memengaruhi pemerolehan pemahaman bacaan. Jika semakin kuat tujuan seseorang dalam membaca maka semakin tinggi pula kemampuan orang itu dalam memahami bacaannya. Sejalan dengan itu, menurut Rahim (2008: 11) ada beberapa tujuan membaca yang mencakup: a) kesenangan, b) menyempurnakan membaca nyaring, c) menggunakan strategi tertentu, d) memperbaharui pengetahuannya tentang suatu topik, e) mengaitkan informasi baru dengan informasi yang telah diketahuinya, f) memeroleh informasi untuk laporan lisan 
dan tertulis, g) mengonfirmasikan atau menolak prediksi, h) menampilkan suatu eksperimen atau mengaplikasikan informasi informasi yang diperoleh dari suatu teks dalam beberapa cara lain, i) mempelajari tentang struktur teks, dan j) menjawab pertanyaan-pertanyaan yang spesifik. Sejalan dengan itu, menurut Wiryodijoyo (2001: 57) tujuan membaca adalah mengetahui isi materi yang adad lam bacaan dan mengerti informasi yang ada di dalamnya.

Slameto (2010: 57) mengatakan bahwa minat adalah kecenderungan yang tetap untuk memerhatikan dan mengenang beberapa kegiatan. Kegiatan yang diminati seseorang diperhatikan terus menerus yang disertai dengan rasa senang. Minat selalu diikuti dengan perasaan senang dan dari situ diperoleh kepuasan. Minat besar pengaruhnya terhadap belajar, karena bila bahan pelajaran yang dipelajari tidak sesuai dengan minat siswa, siswa tidak akan belajar dengan sebaik-baiknya. Menurut Hurlock (2004: 114), minat merupakan sumber motivasi yang mendorong orang untuk melakukan apa yang mereka inginkan bila mereka bebas memilih.

Kurangnya minat baca di Sekolah Menengah Kejuruan Negeri di Jakarta Selatan bisa diakibatkan oleh faktor internal dan faktor eksternal. Faktor internal adalah faktor yang berasal dari diri sendiri yaitu tidak adanya kemauan atau minat baca dari diri sendiri. Adapun faktor eksternal adalah faktor dari luar diri yaitu keluarga, sekolah dan masyarakat.

Faktor keluarga merupakan kebiasaan dari keluarga itu sendiri apakah keluarga tersebut ibu bapak serta anggota lainnya menyenangi membaca di rumah setiap hari atau tidak. Masih banyak orang tua di rumah senang menonton televisi atau sibuk dengan gawainya pada saat jam belajar sehingga anak-anaknya ikut menirukan hal serupa, lupa untuk memerhatikan anaknya membaca atau belajar di rumah.

Faktor sekolah, guru tidak semuanya membiasakan siswa untuk gemar membaca, seperti membaca di perpustakaan atau kegiatan literasi selama 15 menit sebelum memulai pelajaran. Perpustakaan jarang sekali dikunjungi siswa untuk membaca, hanya Sebagian guru saja yang meminta siswa membaca di perpustakaan.

Masalah lain yang terjadi pada pelajaran bahasa Indonesia di beberapa sekolah di Jakarta pelajar malas untuk menulis, penulis sering menjumpai siswa SMK ditugaskan mengamati dan menceritakan pengalaman sendiri selama satu jam pelajaran dalam bentuk tulisan tetapi karangan belum selesai. Belum lagi memerhatikan tulisan siswa dari segi kalimat dan menjadi karangan deskripsi.

Penyebab siswa kurang menyukai menulis bisa saja disebabkan kebiasaan guru memberi tes pilihan ganda sehingga siswa hanya memilih jawaban a, b, c, d atau e. Siswa kurang berkreasi mengembangkan argumentasi, mengasah bakat yang mereka miliki, menuangkan dalam bentuk tulisan yang teratur sampai menjadi sebuah karangan deskripsi.

Nurgiyantoro (2001: 213), faktor-faktor yang perlu dipertimbangkan dalam memilih bahan yang diujikan adalah : 1) bahan tes kosakata; yang memerhatikan: (a) tingkat dan jenis sekolah; (b) tingkat kesulitan kosakata, (c) kosakata pasif dan aktif, (d) kosakata umum, khusus dan ungkapan; 2) Tingkatan 
tes kosakata yang digunakan dengan menggunakan taksonomi Bloom dalam tes kosakata antara lain : (a) tes kosakata tingkat ingatan, (b) tes kosakata tingkat pemahaman, (c) tes kosakata tingkat penerapan, (d) tes kosakata tingkat analisis. Tes kosakata tingkat ingatan (C1) sekadar menuntut siswa untuk mengingat makna, sinonim/antonym, definisi, istilah, atau ungkapan yang terdapat dalam bacaan. Tes kosakata tingkat pemahaman (C2) menuntut siswa untuk dapat memahami makna, maksud, pengertian, atau mengungkapkan dengan cara lain. Tes kosakata tingkat penerapan (C3) menuntut siswa untuk dapat memilih dan menerapkan kata-kata, istilah, atau ungkapan tertentu dalam suatu bacaan. Jadi, dalam tes ini sudah bersifat produktif. Tes kosakata tingkat analisis (C4) dalam tes ini siswa dituntut untuk melakukan kegiatan otak (kognitif) yang berupa analisis, baik berupa analisis terhadap kosakata yang diujikan atau kosakata yang akan diterapkan.

Ketidakberhasilan pengajaran menulis karangan deskripsi tingkat SMK dipengaruhi banyak faktor. Faktor tenaga pengajar, jarang ditemukan seorang pengajar bahasa dan sastra yang berprofesi sebagai seorang pengarang atau penulis yang produktif. Padahal pengajar yang berpengalaman mencipta puisi, cerita pendek, novel dan naskah drama tentu akan lebih baik cara mengajarnya dibandingkan seorang pengajar yang hanya mengajar kemampuan menulis dengan bekal kemampuan teoritik.

Selain faktor pengajar, faktor siswa juga tidak kalah pentingnya. Ketidakmampuan siswa berpikir kreatif dan penguasaan kalimat yang baik membuat siswa sulit mengekspresikan apa yang ingin siswa tulis dalam sebuah karya. Penguasaan kalimat dapat dilakukan jika siswa menulis secara aktif dan dapat menjadi sebuah karya. Penguasaan kalimat dapat dilakukan jika siswa mampu memahami syarat terbentuknya kalimat dan membuat kalimat yang kohesi dan koherensi. Banyak mengetahui kosakata juga dapat membantu siswa untuk membuat kalimat dalam menulis karangan deskripsi.

Berdasarkan uraian di atas, penulis tertarik untuk memilih judul penelitian berikut "Pengaruh Penguasaan Kosakata dan Minat Baca terhadap Kemampuan Menulis Teks Deskriptif Bahasa Indonesia." Penulis berharap setelah siswa memiliki minat membaca yang tinggi tanpa paksaan dari siapa pun, maka siswa akan menguasai kalimat dengan benar dan mampu mengembangkannya menjadi karangan deskripsi.

\section{METODE}

Penelitian ini dilaksanakan pada siswa Sekolah Menengah Kejuaruan (SMK) yaitu di SMKN 6 dan SMKN 29 Jakarta tahun pelajaran 2019/2020. Pemilihan tempat penelitian didasarkan pada pertimbangan tujuan penelitian yaitu mengetahui minat baca dan penguasaan kosakata terhadap keterampilan menulis teks deskriptif. Penelitian dilakukan dalam dua tahap, tahap pertama dilakukan penelitian pendahuluan yaitu mengumpulkan data terkait dengan jumlah sampel yang akan dijadikan objek penelitian. Tahap kedua melakukan uji coba instrumen dan ditindaklanjuti dengan penelitian.

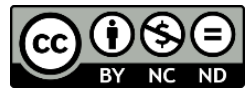


Pada penelitian ini, penulis mengunakan metode survei yaitu dengan mandatangi langsung objek penelitian, sedangkan pendekatan analisis yang digunakan adalah analisis korelasional. Metode survei ini salah satu metode dalam penelitian yang pelaksanaannya tidak ada perlakuan terhadap objek penelitian, tetapi hanya melihat, mencatat dan menganalisis data yang ditemukan sesuai dengan fakta yang terjadi di lapangan. Penulis menemui kendala dimana di bulan Maret pertengahan pada tanggal 17 Maret 2020 negara Indonesia terserang wabah Covid-19 yang berdampak besar bagi penulis sehingga tidak bisa menuntaskan pertemuan tatap muka.

Penelitian yang akan dilakukan bersifat penelitian sampel yaitu penelitian yang menjadikan Sebagian kelas X sebagai sampel untuk mewakili keseluruhan siswa kelas X SMK Negeri di Jakarta Selatan. Penelitian ini menggunakan salah satu metode yang ada dalam penelitian ilmiah yaitu metode survey korelasional.

Menurut Sugiono populasi adalah wilayah generalisasi yang terdiri atas objek/subjek yang mempunyai kualitas dan karakteristik tertentu yang ditetapkan oleh peneliti untuk dipelajari dan kemudian ditarik kesimpulannya. (Sugiyono, 2003: 215). Populasi dalam penelitian ini adalah siswa kelas dan SMKN 29 Jakarta tahun pelajaran 2019/2020.

Sampel dalam penelitian ini adalah sebagian siswa SMK Negeri di Jakarta Selatan dengan ukuran populasi yang berjumlah 500 siswa. Menurut Sugiyono (2003: 62) menyatakan "bahwa berdasarkan tabel Krecjie dalam melakukan perhitungan ukuran sampel didasarkan atas kesalahan 5\%. Jadi sampel yang diperoleh itu mempunyai kepercayaan $95 \%$ terhadap populasi. Berdasarkan tabel Krecjie dapat dilihat bahwa bila jumlah populasi 100 maka sampelnya 80, bila populasi 1000 maka sampelnya 278, bila sampelnya 10.000 maka sampelnya 370 dan bila jumlah populasinya 100.000 maka jumlah sampelnya 384, dengan demikian makin besar populasi makin kecil prosentase sampelnya sama, misalnya $10 \%$.

Dalam penelitian ini teknik pengambilan sampel menggunakan proposional sample rsndom sampling. Jumlah populasi sebanyak 500 siswa sedang diambil untuk penelitian 60 siswa dari jumlah populasi.

Pengumpulan data yang digunakan dalam penelitian ini menggunakan beberapa teknik yaitu: 1) Wawancara dilakukan dengan mewawancarai secara langsung guru mata pelajaran dan kepala sekolah guna mendapatkan data terkait dengan penelitian. 2) Penyebaran angket kepada siswa sebagai sampel terkait dengan minat membaca dan penguasaan kosakata. 3) Tes kinerja kepada siswa untuk mengukur keterampilan menulis teks deskriptif.

Dalam penelitian ini digunakan teknik pengumpulan data melalui pengamatan awal, angket dan tes akhir. Ppenelitian ini menggunakan metode deskriptif analisis. Adapun teknik pengumpulan data yang digunakan melalui survei, yakni dengan menggunakan angket kuesioner ditujukan kepada siswa kelas X.

Penelitian ini dilakukan dengan mengumpulkan data kualitatif, yang selanjutnya akan disajikan dalam bentuk angka untuk diujii secara verivikatif sesuai dengan analisis data. Dalam suatu penelitian diperlukan instrumen untuk 
mengumpulkan data, penyusun instrumen yang tepat dapat digunakan untuk merekrut apa yang dimaksudkan dalam penelitian.

Instrumen atau alat yang digunakan dalam upaya pengumpulan data penelitian ini terbagi dalam tiga model. Model pertama, berbentuk data yang diambil dari perpustakaan SMK Negeri di Jakarta Selatan dan kuesioner yang disusun menurut model skala Likert, untuk mewakili variabel minat membaca siswa. Model kedua berbentuk kuesioner yang disusun menurut skala Likert, kuesioner ini untuk mewakili variabel pengusaaan kosakata, sedangkan model ketiga, berbentuk tugas esai, untuk mewakili keterampilan menulis teks deskriptif.

\section{HASIL DAN PEMBAHASAN Hasil}

Tabel 1. Koefisien Regresi Pengaruh Variabel $X_{1}$ dan $X_{2}$ terhadap $Y$

\begin{tabular}{|c|c|c|c|c|c|c|}
\hline \multirow{2}{*}{\multicolumn{2}{|c|}{ Model }} & \multicolumn{2}{|c|}{ Unstandardized Coefficients } & \multirow{2}{*}{$\begin{array}{c}\text { Standardized } \\
\text { Coefficients } \\
\text { Beta }\end{array}$} & \multirow[t]{2}{*}{$t$} & \multirow[t]{2}{*}{ Sig. } \\
\hline & & B & Std. Error & & & \\
\hline \multirow{3}{*}{1} & (Constant) & $-4,646$ & 6,572 & &,- 707 & .483 \\
\hline & Penguasaan Kosakata & .253 & 049 & .410 & 5,127 &, 000 \\
\hline & Minat Baca & ,339 & .048 & .571 & 7,134 &, 000 \\
\hline
\end{tabular}

a. Dependent Variable: Keterampilan Menulis Teks Deskriptif

\section{Pengaruh Penguasaan Kosakata dan Minat Baca Secara Bersama-Sama terhadap Keterampilan Menulis teks Deskriptif Bahasa Indonesia}

Hipotesis pengaruh ini adalah :

$$
\begin{aligned}
& H_{0}: \beta_{1}=\beta_{2}=0 \\
& H_{0}: \beta_{1} \neq 0 ; \beta_{2} \neq 0
\end{aligned}
$$

$\mathrm{H}_{0}$ : Tidak terdapat pengaruh yang signifinikan penguasaan kosakata dan minat baca bersama-sama terhadap keterampilan menulis teks deskriptif bahasa Indonesia.

$\mathrm{H}_{1}$ :Terdapat pengaruh yang signifikan pengusaan kosakata dan minat baca secara bersama-sama terhadap keterampilan menulis teks deskriptif bahasa Indonesia.

Dari tabel di atas terlihat bahwa koefisien korelasi ganda pengaruh variabel bebas pengusaan kosakata $\left(\mathrm{X}_{1}\right)$ dan minat baca $\left(\mathrm{X}_{2}\right)$ secara bersama-sama terhadap keterampilan menulis teks deskriptif bahasa Indonesia (Y) adalah 0,850.

Perhitungan pengujian signifikansi koefisien korelasi ganda ini bisa dilihat pada tanda signifikan (a) pada kolom R. Dari perhitungan tersebut diperoleh bahwa koefisien korelasi tersebut signifikan, dengan kata lain bahwa terdapat pengaruh yang signifikan variabel bebas penguasaan kosakata $\left(\mathrm{X}_{1}\right)$ dan minat baca $\left(\mathrm{X}_{2}\right)$ secara bersama-sama terhadap keterampilan menulis teks deskriptif bahasa Indonesia (Y). Sedangkan koefisien determinasinya sebesar 72,2 \% menunjukkan bahwa besarnya kontribusi penguasaan kosakata $\left(\mathrm{X}_{1}\right)$ dan minat baca $\left(\mathrm{X}_{2}\right)$ secara bersama-sama memengaruhi keterampilan menulis teks 
deskriptif bahasa Indonesia (Y) adalah sebesar 72,2 \% sisanya $(27,8 \%)$ karena pengaruh faktor lain.

Untuk pengujian hipotesis melalui analisis regersi diperoleh hasil perhitungan terlihat pada tabel diperoleh persamaan garis regresi yang merepresentasikan pengaruh variabel $\mathrm{X}_{1}$ dan $\mathrm{X}_{2}$ terhadap variabel $\mathrm{Y}$, yaitu $\mathrm{Y}=$ $4,645+0,253 X_{1}+0,339 X_{2}$.

Pengujian signifikan garis regrasi tersebut adalah dengan memerhatikan hasil perhitungan yang ada pada tabel. Menurut ketentuan yang ada, kriteria signifikan regresi tersebut adalah " jika $\mathrm{Sig}<0,05$ maka $\mathrm{H}_{0}$ ditolak" atau "jika $F_{\text {hitung }}>F_{\text {tabel }}$ maka $\mathrm{H}_{0}$ ditolak", yang berarti bahwa koefisien regresi ttersebut signifikan, dengan kata lain terdapat pengaruh yang signifinikan variabel bebas $\mathrm{X}_{1}$ dan $\mathrm{X}_{2}$ terhadap variabel terikat $\mathrm{Y}$. Nilai Sig adalah bilangan yang tertera pada kolom $\mathrm{F}$ dalam tabel, sedangkan nilai $\mathrm{F}_{\text {tabel }}$ adalah nilai tabel distribusi $\mathrm{F}$ untuk taraf nyata $5 \%$ dengan derajat pembilang $(\mathrm{k})=2$ dan derajat penyebut $(\mathrm{n}-\mathrm{k}-1)=$ 58 dimana $\mathrm{n}$ adalah banyaknya responden, $\mathrm{k}$ adalah banyaknya variabel bebas.

Dari tabel terlihat bahwa nilai Sig $=0,000<0,05$ dan $\mathrm{F}_{\text {hitung }}=74,051$, maka $\mathrm{H}_{0}$ ditolak yang berarti bahwa koefisien regresi tersebut signifikan. Dengan kata lain bahwa terdapat pengaruh yang signifikan variabel bebas penguasaan kosakata $\left(X_{1}\right)$ dan minat baca $\left(X_{2}\right)$ secara bersama-sama memengaruhi keterampilan menulis teks deskriptif bahasa Indonesia (Y) . Dari hasil pengujian korelasi maupun regresi tersebut maka dapat disimpulkan bahwa terdapat pengaruh yang signifikan variabel penguasaan kosakata $\left(\mathrm{X}_{1}\right)$ dan minat baca $\left(\mathrm{X}_{2}\right)$ secara bersama-sama memengaruhi keterampilan menulis teks deskriptif bahasa Indonesia (Y).

\section{Pengaruh Penguasaan Kosakata terhadap Keterampilan Menulis Teks Deskriptif Bahasa Indonesia}

Hipotesis pengaruh ini adalah :

$$
\begin{aligned}
& H_{0}: \beta_{1}=0 \\
& H_{1}: \beta_{1} \neq 0
\end{aligned}
$$

$\mathrm{H}_{0}$ : Tidak terdapat pengaruh penguasaan kosakata terhadap keterampilan menulis teks deskriptif bahasa Indonesia.

$\mathrm{H}_{1}$ : Terdapat pengaruh penguasaan kosakata terhadap keterampilan menulis teks deskriptif bahasa Indonesia.

Berdasarkan Tabel di atas dan persamaan regresi ganda menunjukkan bahwa hipotesis statistik $\mathrm{H}_{0}$ : Tidak ada pengaruh variabel bebas penguasaan kosakata $\left(\mathrm{X}_{1}\right)$ terhadap keterampilan menulis teks deskriptif bahasa Indonesia( $\left.\mathrm{Y}\right)$ ditolak karena nilai sig $=0.000<0.05$ dan thitung $=5,127$ maka $\mathrm{H}_{0}$ ditolak yang berarti bahwa koefisien regresi tersebut signifikan variabel bebas $\mathrm{X}_{1}$ (pengusaan kosakata) terhadap variabel terikat $\mathrm{Y}$ (keterampilan menulis teks deskriptif bahasa Indonesia)

Dari hasil pengujian korelasi maupun regresi tersebut maka bisa disimpulkan bahwa terdapat pengaruh yang signifikan variabel penguasaan kosakata $\left(\mathrm{X}_{1}\right)$ terhadap variabel terikat keterampilan menulis teks deskriptif bahasa Indonesia (Y). 


\section{Pengaruh Minat Baca terhadap Keterampilan Menulis Teks Deskriptif Bahasa Indonesia}

Hipotesis pengaruh ini adalah

$$
\begin{aligned}
& H_{0}: \beta_{1}=0 \\
& H_{0}: \beta_{1} \neq 0
\end{aligned}
$$

$\mathrm{H}_{0}$ : Tidak terdapat pengaruh minat baca terhadap keterampilan menulis teks deskriptif bahasa Indonesia.

$\mathrm{H}_{1}$ : Terdapat pengaruh minat baca terhadap keterampilan menulis teks deskriptif bahasa Indonesia.

Berdasarkan tabel di atas dan persamaan regresi ganda menunjukkan bahwa hipotesis statistik $\mathrm{H}_{0}$ : Tidak ada pengaruh variabel minat baca $\left(\mathrm{X}_{2}\right)$ terhadap variabel keterampilan menulis teks deskriptif bahasa Indonesia(Y) ditolak karena nilai sig $=0.000<0.05$ dan $t_{\text {hitung }}=7,134$. Hal ini berarti $\mathrm{H}_{1}$ dapat diterima. Dari hasil pengujian korelasi maupun regresi tersebut maka bisa disimpulkan bahwa terdapat pengaruh yang signifikan variabel minat baca $\left(\mathrm{X}_{2}\right)$ terhadap variabel keterampilan menulis teks deskriptif bahasa Indonesia (Y).

\section{Pembahasan}

Penelitian ini untuk mengetahui pengaruh antara penguasaan kosakata $\left(\mathrm{X}_{1}\right)$ dan minat baca $\left(\mathrm{X}_{2}\right)$ secara bersama-sama terhadap keterampilan menulis teks deskriptif bahasa Indonesia (Y)

\section{Pengaruh Penguasaan Kosakata dan Minat Baca Secara Bersama-sama terhadap Keterampilan Menulis Teks Deskriptif Bahasa Indonesia}

Persamaan regresi telah memenuhi persyaratan yang diperlukan antara lain variabel dependen mengikuti distribusi normal dan hasil uji linearitas diperoleh persamaan regresi variabel dependent terhadap variabel independent adalah linier, begitu juga hasil uji multikolinieritas, dapat dikatakan tidak terjadi multikolinieritas.

Dari deskripsi data setelah dilakukan analissi korelasi diperoleh koefisien korelasi sebesar 0,850 dan koefisien determinasi sebesar 72,2\%, setelah dilakukan pengajuan dengan program SPSS terbukti bahwa koefiesien korelasi tersebut signifikan. Hal ini berarti bahwa terdapat pengaruh variabel bebas penguasaan kosakata dan minat baca secara bersama-sama terhadap variabel terikat keterampilan menulis teks deskriptif bahasa Indonesia.

Dari analisis regresi diperoleh persamaan garis regresi ganda $\mathrm{Y}=-4,645+$ $0,235 X_{1}+0,339 X_{2}$. Nilai konstanta $=-4,645$ menunjukkan bahwa siswa dengan penguasaan kosakata dan minat baca paling rendah sulit bagi siswa tersebut untuk bisa meraih keterampilan menulis teks deskriptif bahasa Indonesia yang baik. Sedangkan nilai koefisien regresi sebesar 0,235 dan 0,339 menunjukkan bahwa terdapat pengaruh positif variabel $\mathrm{X}_{1}$ (penguasaan kosakata) dan $\mathrm{X}_{2}$ (minat baca) secara bersama-sama terhadap variabel terikat $\mathrm{Y}$ (keterampilan menulis teks deskriptif bahasa Indonesia), dan setiap kenaikan satu unit penguasaan kosakata dan sekaligus dengan kenaikan satu unit variabel minat baca akan diikuti dengan kenaikan keterampilan menulis teks deskriptif bahasa Indonesia, sebesar 0,574 unit $=(0,235+0,339)$. 
Dari pengujian signifikan koefisien regresi yang juga dilakukan dengan program SPSS diperoleh bahwa koefisien regresi tersebut signifikan, yaitu ditunjukkan oleh nilai $\mathrm{Sig}=0.000$ dan $\mathrm{F}_{\text {hitung }} 74,051$ sedangkan $\mathrm{F}_{\text {tabel }}=3,15$ sehingga nilai Sig $<0,05$ dan $\mathrm{F}_{\text {hitung }}>\mathrm{F}_{\text {tabel }}$ atau regresi tersebut signifikan, yang brarti benar bahwa terdapat pengaruh yang positif variabel bebas $\mathrm{X}_{1}$ (penguasaan kosakata) dan $\mathrm{X}_{2}$ (minat baca) secara bersama-sama terhadap variabel terikat $\mathrm{Y}$ (keterampilan menulis teks deskriptif bahasa Indonesia).

Berdasarkan informasi kuantitatif dan teori tersebut peneliti berkesimpulan bahwa penguasaan kosakata dan minat baca mempunyai pengaruh yang positif dan signifikan secara bersama-sama terhadap keterampilan menulis teks deskriptif bahasa Indonesia.

\section{Pengaruh Penguasaan Kosakata terhadap Keterampilan Menulis Teks Deskriptif Bahasa Indonesia}

Dari pengujian hipotesis diperoleh bahwa nilai Sig $=0.000$ dan $\mathrm{t}_{\text {hitung }}=$ 5,127 , sedangkan $t_{\text {tabel }}=1,67$. Karena nilai Sig $<0,05$ dan $t_{\text {thitung }}>t_{\text {tabel }}$ maka H0 ditolak yang berarti terdapat pengaruh yang signifikan variabel bebas X1 (penguasaan kosakata) terhadap variabel terikat Y (keterampilan menulis teks deskriptif bahasa Indonesia).

Hasil penelitian menunjukkan bahwa ada pengaruh penguasaan kosakata terhadap keterampilan menulis teks deskriptif bahasa Indonesia. Setiap kenaikan satu unit penguasaan kosakata akan diikuti dengan kenaikan keterampilan menulis teks deskriptif bahasa Indonesia sebesar 0,253 unit, ceteris paribus atau variabel penguasaan kosakata tidak berubah.

Dari informasi kuantitatif dan teori tersebut maka peneliti menyimpulkan bahwa terdapat pengaruh yang signifikan pengusaan kosakata terhadap keterampilan menulis teks deskriptif bahasa Indonesia.

\section{Pengaruh Minat Baca terhadap Keterampilan Menulis Teks Deskriptif Bahasa Indonesia}

Dari pengujian hipotesis diperoleh bahwa nilai Sig $=0,000$ dan thitung $=$ 7,134 sedangkan tabel $=1,67$. Karena nilai Sig $<0,05$ dan thitung $>$ t tabel maka $\mathrm{H}_{0}$ ditolak yang berarti terdapat pengaruh yang signifikan variabel bebas $\mathrm{X}_{2}$ (minat baca) terhadap variabel terikat $\mathrm{Y}$ (keterampilan menulis teks deskriptif bahasa Indonesia).

Berdasarkan hasil pengujian dinyatakan ada pengaruh variabel minat baca terhadap variabel keterampilan menulis teks deskriptif bahasa Indonesia. Setiap kenaikan satu unit minat baca akan diikuti dengan kenaikan keterampilan menulis teks deskriptif bahasa Indonesia sebesar 0,339 unit, ceteris paribus atau variabel minat baca tidak berubah.

Dari informasi kuantitatif dan teori tersebut maka peneliti berasumsi bahwa terdapat pengaruh signifikan minat baca terhadap keterampilan menulis teks deskriptif bahasa Indonesia. 


\section{SIMPULAN}

Berdasarkan hasil dan pembahasan, dapat disimpulkan bahwa terdapat pengaruh yang signifikan penguasaan kosakata dan minat baca secara bersamasama terhadap keterampilan menulis teks deskriptif bahasa Indonesia siswa SMK Negeri di Jakarta Selatan. Hal ini dibuktikan dengan nilai Sig $=0,000<0,05$ dan $\mathrm{F}_{\text {hitung }}=74,051$. Terdapat pengaruh yang signifikan penguasaan kosakata terhadap keterampilan menulis teks deskriptif bahasa Indonesia siswa SMK Negeri di Jakarta Selatan. Hal ini dibuktikan dengan nilai $\mathrm{Sig}=0,000<0,05$ dan $\mathrm{t}_{\text {hitung }}=$ 5,127 . Terdapat pengaruh yang signifikan minat baca terhadap keterampilan menulis teks deskriptif bahasa Indonesia siswa SMK Negeri di Jakarta Selatan. Hal ini dibuktikan dengan nilai Sig $=0,0000<0,05$ dan $\mathrm{t}_{\text {hitung }}=7,134$, yang berarti terdapat pengaruh yang signifikan.

\section{DAFTAR PUSTAKA}

Akhadiah, S. (2002). Pembinaan kemampuan menulis bahasa Indonesia. Jakarta: Gelora Aksara Pratama.

Brown, H. G. (2001). Teaching by principles: Interactive approach to language. pedagogy. New York: San Francisco State University.

DeCarrico, J. (2002), Grammar, an introduction to applied linguistic, London: Hodder Education.

Hurlock, E. (2004). Psikologi perkembangan. Jakarta: PT Gramedia Pustaka.

Nurhadi. (2000). Membaca cepat dan efektif. Bandung: Sinar Baru.

Nurgiyantoro, B. (2001). Menulis secara populer. Jakarta: Pustaka Jaya.

Poerwadarminta. (2007). Kamus umum bahasa Indonesia. Jakarta: PN Balai Pustaka.

Rachmawati. (2005). Indahnya bahasa dan sastra Indonesia. Jakarta: Departemen Pendidikan Nasional.

Rahim, F. (2008). Persiapan membaca di sekolah dasar. Jakarta: Bumi Aksara.

Rohman, F. (2005). Pengembangan pembelajaran membaca. Jawa Tengah: Dinas Pengembangan Tenaga Kependidikan.

Slameto. (2010). Belajar dan faktor-faktor yang memengaruhinya. Jakarta: Rineka Cipta.

Sugiyono, P. (2003). Metode penelitian administrasi. Bandung: Alfabeta.

Tarigan, H. G. (2005). Membaca sebagai suatu keterampilan berbahasa, Bandung: Angkasa.

Wiryodijoyo, S. (2001). Membaca: Strategi, pengantar, dan tekniknya, Yogyakarta: Aksara. 